\title{
帮助少数民族創立、改進和改革 文字工作的情况和問題.
}

\author{
傅 禁 耡 \\ （中國科学院語言研究所）
}

\section{引}

我國是一个多民族的國家。各民族人民正在共迹党的領導下，程極地淮行斻会主义义 建設和社会主义改造。虽然各少数民族的狆展目前还是很不本衡的, 但是都要和漢族击 闹过渡到社会主义社会。現在我國經济建設的速度日益㘿長，而許多少数民族地区的文 化敉育事業还赶不上經济建設的需要。農業合作化运动的漓湖已經來到了, 可是有許多 民族还沒有交宇或有交字而不完备, 这种情况嚴重地阻碍了这些民族經济、政治和交化 上的發展。

解放以本，党的民族政策很早就提出了帮助少数民族發展語言交字的問題。中華人 民共和國念法規定各民族都有使用和發展自己的語言文字的自的。在發展國瓦䌊济的第 一个五年計划中，也提出了“对於那些还沒有交字的尼族应該努力帮助他們㓱造向已的 交字”和發展少数民族地区的交化教育事業等項任务。由此可見, 帮助少数跑族刢主、 改淮和改革交字, 是党在过渡时期民族工作方面急需解决的一个很重要的問題。

按照馬克思主义的覌点, 一切事物都在运动着、变化着、齐生着利淮逝管。在我們 建設社会主义社会的國家里, 語言的發展必然地經歷着由低級到活級、由分散到集中的 过程。民族交化也一定会依賴使胉本族語言的初等义务敉育的普遍施行而以新的力量弡 展起來; 只有在民族交化發展的条件下，才能使各民族更有效地参加社会主义建設的析 業。因此，根据各民族的需要和意願來進行創立、改進和改革民族文字的工作是非常必 要的。通过这一工作，我國各民族的語言一定会更加互相丰富和發展起來，上族形式计. 会主义內容的文化一定会空前地繁荣起來, 这样才能使交化教育建設和日以于里的縒济 建設相適应，使各民族迅速地發展成社会主义民族。这不只是一作細緻的科学工作，也 是一个碾藏的政治任务。

\section{一 少数民族語青文字的简要情况}

我國少数民族語言, 大体上可分屬於漢藏、阿尔泰、南亞、印欧 4 个語系。屬於漢

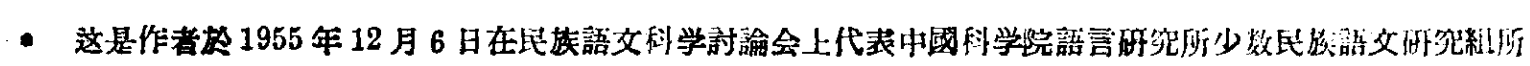
作的报告。 


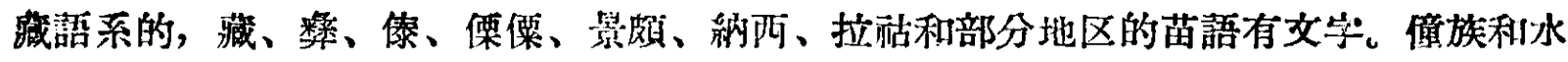
家族原來曾用漢字和漢字变体形式或少数像形字記载絓文和歌詞，佈依、儂、沙、娴、 黎、璔、民家、哈尼、烍和大部分苗語都一间沟有交字。屬於阿尔泰語系的，維吾尔、

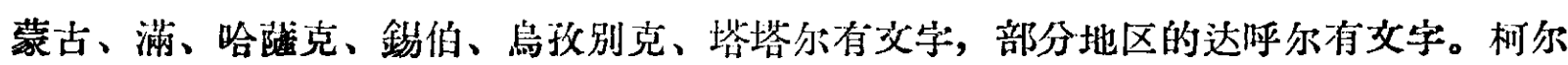
克孜族篔有文字，东鄉、土族 (清海、甘藏)、保安、撒拉、裕固、索偷、鄂偷清等都沒 有文。。屬於南亞語系的，卡瓦有文字，布朗、綳壠沒有文字。屬於印欧語系的只有塔 吉克語, 没有文字。朝鮮語和高山語的系屬还沒定論, 朝鮮語有交字, 俩山語的情况, 䏌待調查。

滿族只有少数村落的部分人士还懂得原來的語言文字，絕大多数人已經探用了漢語 文。其他各民族除个別地区的少数人有放棄本民族語言探用另一种語言的以外，都拿本 族語言作交际工具。

由於不同的歷史条件，有一个民族使用兩种或更多种的文字的：傣交有 5 种，傈潥 文、景頗文、納西文、苗文各有 3 种，蒙文、䈘文各有 2 种。因此，虽然僅只有 20 个 左右的民族有文字，可是共有 30 多种文字。在这 30 多种交字中，有一种表意文学，就 是納西族的“东巴”文; 有 3 种音節文字, 就是納西族的“哥巴”文，歷史較長的一种䇣文

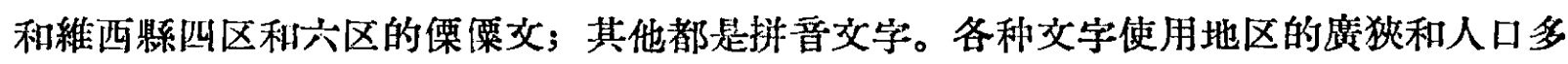
少也会相益很大, 例如: 使用傣伤文的有西双版納自治州和孟連一帶約 15 万人口的地区, 会文字的約有 3 万人; 使用金平傣文的只有金平俥的第三区約有 3,400 多人口的地方，会 文字的不过 100 人。在帝國主义傳敎士拟制的文学当中，有些只在敎堂里經書上使用，

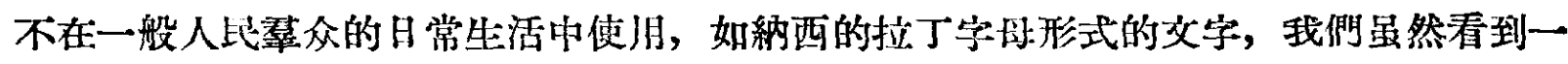
本印出來的基督敉讚美詩, 但是还没有找到一个能認識的人; 貴州东部注音字母的苗文, 能認識的人也很少, 絕大多数苗人都不知道有这种文字。在原有文字中也有些文学是很 不完备的，例如：帝國主义傳㸚士根据布鱙方言創造了卡瓦文。可是布鋥方言的輔音元 音系統是很复襍的, 其中有 12 个輔音和 9 个元音在这种卡瓦交里完全混入其他輔音和元 音，有 2 个輔音韵尾在父字上也完全沒有表示; 因此，有大量的在語言里有嚴格分別的 詞在交字上完全沒有分別。

对於原有交字或没有文字的語言, 都需要組織人力, 有計划地逐步地調查研究方言 分布和同異的情况, 参考其他谷項有关材料, 选定和确定它的标准語的基碄方言和标准 畐, 逐步建立發展各民族書面的和口头的民族共同語。对没有文字的民族, 应該根据語言 使用的具体情况和本民族的自願自擇，帮助創立拼音交字或探用現有的適用的文字。对 原有文孕的民族, 还要研究它們文字的結構原則, 文字和語言的关系以及文字使用的情 㫛, 然后根据本民族的自願自擇, 决定是否進行文字改淮或改革的工作。滿族的絶大多 数人民虽然探用了漢語文, 但是对於滿族原有的語言交字也須淮行調查研究, 以便了解 他們丰富的歷史交献並進行通古斯語族語言的比較研究。

\section{二 帮助少数民族創立、改進和改革文字工作的情况}

中國科学院語言研究所遵照政务院 1951 年“关於民族事务的几項决定”中“帮助向無 文字的民族創立交字, 帮助交字不完备的赽族逐漸流实其文字”的指示, 已經派語文工作 
榢分別到四川（包括原西康省）、堅西、貴州、云南等省作重点的調查研究。一方面为帮

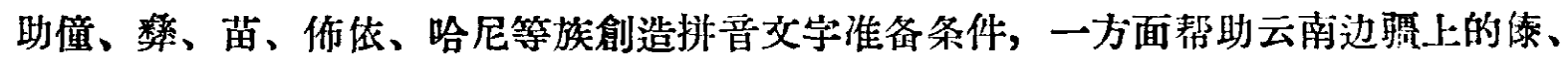

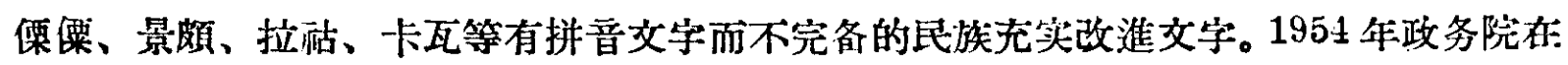
对文化教育委員会民族語言文字研究指導委員会和中央人民政府民族事务委員会 “关於 帮助向無交字的民族創立交字問題的报告”的批复中，指示了在創立交字工作中各机構 分工的原則，韭責成中國科学院語言研究所和中央人民政府民族事务委員会審惨研究， 然后拟訂計划和訂出在一兩个民族中創纹文字的具体方案，开始先在这一兩个民族中逐 步試行。並应䅴結了解情况, 及时总結經驗, 以便在事实証明这些办法确是可行, 而且 其他条件也比較成熟时，逐洀地在別的民族中進行。語言研究所和民族事务委員会逜照 这个指示審㥀研究后, 决定首先在僮族中試行㓣立交字的工作。語言研究所於同年 9 月 和桂西僮族自治区僮族交字研究指導委員会业同組織了僮語工作榢, 对於倍語方言做了 全面的調查和比較研究，同时也搜集了有决决定僮族标准語基礎方言和标准音的其他各

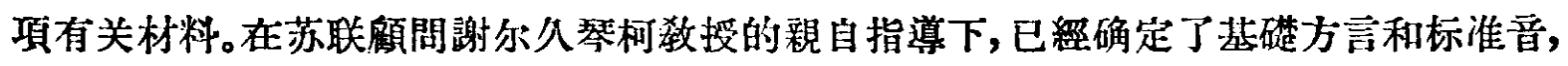

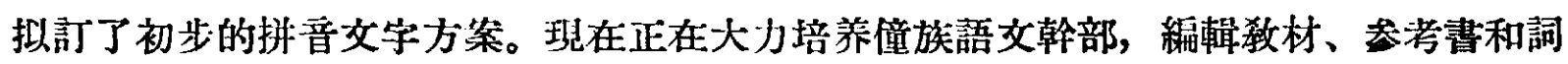
典, 准备 1956 年 3 月起進行試驗, 10 月开始推行。在帮助墥族創立交字的闰时, 对於和 傹語很接近的作依語、倀語、沙部也進行了調查研究並拿它們和僮語進行了初步的比較。 根据現有朴料看, 說媛語和沙語的人有和墥族使用一种交字的可能。关於佈依族能否和 僮族使用一种交字的問題, 正在研究。

在進行僮族文字工作以前, 語言研究所的研究人員冒和繁族知倳分子合作，在四川 創立了一种用拉丁字母拼音的新文。除了在中央民族学院、西南包族学院、西康省立 师范学校、西昌專区民族幹部学㳏、禾山尃区民族幹部学校、民族幹部剖練班、乐山师范 学校、淙山軍分区繁民团淮行了新繁文的实驗教学以外，已經在四川 40 所民族小学中使 用新繁文各科敉科書淮行敉学。編譯了 45 种課本和讀物, 出版了一种新等交双週报。培 养了新篓交师資和研笢編譯幹部 176 人, 現在䇣族成人和在校兒童已經学会新䇣文的有 7,000 多人。維过了 4 年多的敉学和試用的实踐，我們認为帮助禁族㓣立一种拼音文字 以提高人民大众的交化水平, 这种做法是正确的。現在在淮行了新箖交敉学的地区, 族人民在交化知識和政治生活的提高上，是比較㙷著的。但是在新等文的工作中，也陸

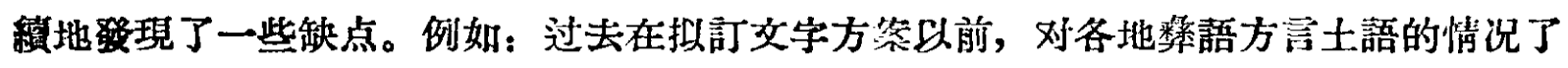
解得不够，个別字母形式和拼密規則还不够簡便精密。我們对新攀交的工作，正在進行 总結, 亚拟修改現有的交字方案。涼山获族自治州也打算成立一个語交工作机構, 我們 㴓为这是必要的。

我國有些民族的拼音交宇，虽然有悠久的歷史，但是在反动統治时代得不到發展的 机会。中華人民共和國成立以后, 有些民族已經提出改淮或改革旧文字的要求。內蒙古 自治区、新疆維吾尔自治区、克孜勒苏柯尔克孜族自治州、云南省德公鉒族景颇族自治 区，西双版納傣族自治州，都成立了語交研究、交宇改革或改進的机構。西双版納和德 公地区已緅完成了雨种像文的改進方案, 正在編譯敉枌、参考書和詞典, 准备試驗和推 行。維吾尔族和哈薩克族对个別宇母和姘宾規則, 都提出了改進的方案。云南省的傈僄 族、提出了初步的創立交字方案，景頗族、拉的族設計了初步的交字改進方案。內蒙古 
自治区人民委員会已經在 1955年 7 月公佈丁“关於推行新蒙认的决定”，在决定中規 定 1955 年下牛年到 1958 年上牛年为准备階段。1958 年.上牛年淮入重点推行新蒙文的 階段，从这时起到 1961 年为从使用旧蒙交过渡到使咸新蒙文的階段。1962 年5 月起完 全施行新蒙艾。

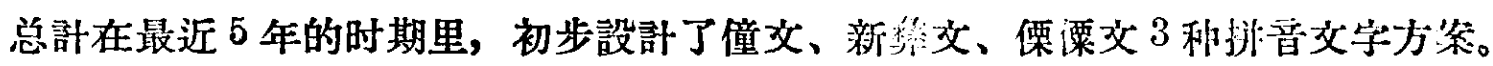

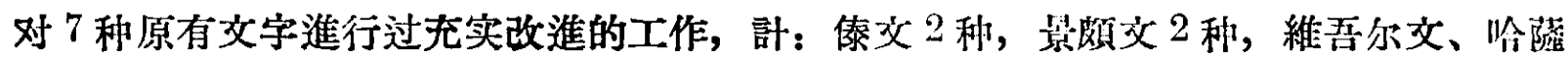

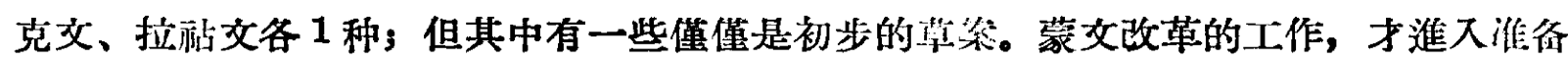
階段。

現在影楸調查研究的工作，語言研究所为了進行席泛深入的調查研究和帮助地方培

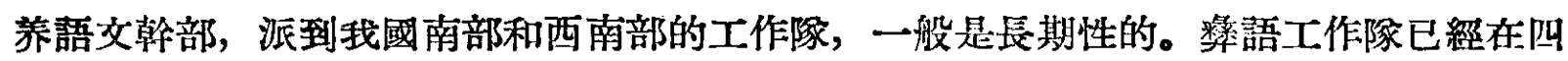

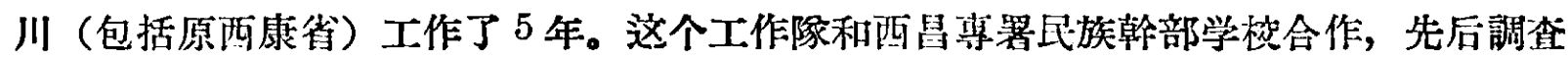

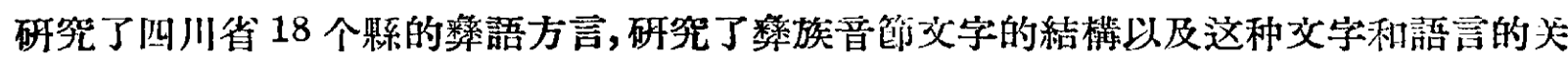
系。語法和詞典的編寫工作已經完成了 $1 / 3$ 。現在这个工作豚的中心任务是帮助阢川私 族修訂現有的文字方案和試驗推行新籘文。我們准得吸收一批云南和贵州本民族的知識 分子，普遍調查䂰究云南、贵州兩省的繁語方言，以便更全面地考虑算族文字問題。

僮語工作榢是从 1952 年就开始工作的。1954 年和僮族自治区合作拱大丁組織，分 西、北、南三路普遍調查了度西省 44 夥的僮語方言, 現在除積極准备試驗推行新創立 $L$ 的 文字以外，正在編第一个全面的“僮語調查报告”。和僮浯工作相配合，在 1952 年䅐派 了一个佈依語調查組到贵州調查研究佈依語方言，已縚曷好一部“佈依語語法研究”，即

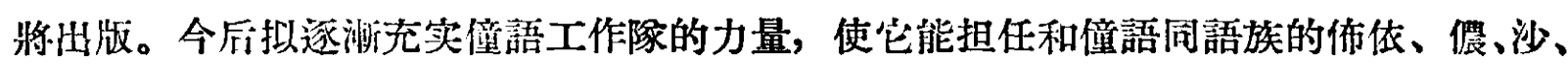
润、水家、黎等語言的呼究。这样就更容易進行比较研究，在創立文字的工作上也能侈 做到应有的联系。

云南工作榢已經秒結在云南工作了 4 年。这个工作榢和云南省民族事务委員会語文 研究室合作，分成几个工作組到云南西部和南部的傣族地区、云南酒部的景颇族傈傈族

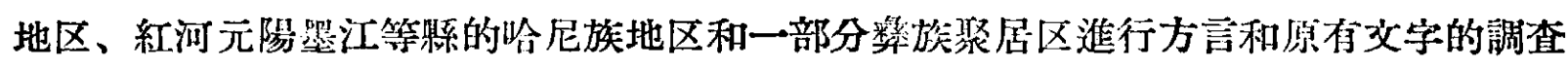

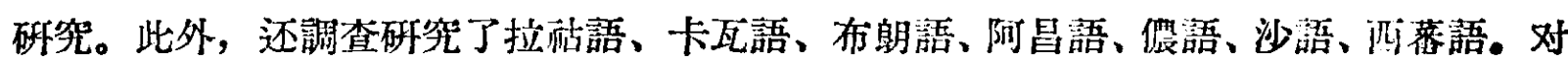
國防綫上儿个主要民族的語言，都進行了音位系統、詞巢和語法的研究，对其他語言也 归納了音位系統，記錄了常用詞巢和一些短句。1955 年 9 月中央民族事务委員 会和語 言研究沂派人协闰苏联顧問謝尔久琴柯教授到云南研究了谷項語言材料和工作豚帮助傣 族、傈保族、景颇族、拉牊族拟訂的文字方案以及帮助哈尼族創立文字的工作步驟，对 这些工作提出了建荼, 把工作大大地向前推進了一步。

苗語工作豚自从 1952 年开始就是由語言呼究所和中央民族学院的力量共同組成的。 这个榢首先調查砰究了贵州东部和西北部的苗語方言证初步研究了四川南部和湖南西部 的苗語方言。1955年父到贵州中部、西部、云南东部和恳西僮族自治区調查苗語方言， 現在对全國苗語方言划分和各种方言的同異，已經提出初步的材料和意見，这对於苗族 文字問題的解决，是有很大的帮助的。

为了帮助我國北部、东北部、阿北部的少数民族發展語言文字和了解各民族語言文 宇的情况及彼此閆的关系，1955年語言研究所、中央民族学院和內蒙古、新疆語文研究机 
情合組了蒙古語族語言和方言調查豚及新疆民族語言調查豚分別到內蒙古自治区、热河、 吉林、黑龍江、甘昔、青海等省和新疆維吾尔自治区進行調查研究。苏联蒙古䓊軎家拒 达叶娃同志親自参加並指導蒙古語族語言和方言調查榢做工作。这个調査榢已經提出关 䑙划分我國蒙古語方言的意見, 並研究了达呼尔、土族、东鄉 3 种語言以及它們和蒙沾語 的关系。对於我國蒙語和蒙古人民共和國蒙語的同異, 也做了初步的比較。这不僅給我 國蒙古文宇改革的工作提供了材料，也給达呼尔、土族、东鄉等族的文字工作，准备了 条件。新疆民族語言調査隊对維吾尔語、哈薩克語、柯尔克孜語做了重点調查研究, 並 拿这些語言和苏联的維吾尔語、哈限克語、吉尔吉斯語做了初步的比較。对於錣伯語和 塔吉克語也進行了初步的調查。这个調查豚的工作对於今后帮助新疆各民族淮行語言交 字的研究，也提出了参考材料。

藏族有統一的書面語言和丰富的文化遗座，但是在現階段，各地方言士語的盖別还 是相当大的。过去中央民族学院和語言研究所調查研究过拉薩、日佲則、昌都、安多的 方言, 並做过初步的比較研究。今后应組繊力量逐步廣泛樑入地調查呼究藏語方言, 並 柪䍃比研究的工作。对於藏語的文献資料和本民族关於藏語文的著作，也需要進行研 究。

关於培养幹部方面, 中央民族学院語文系自 1951 年起, 陸縞开办了藏、蒙、維吾

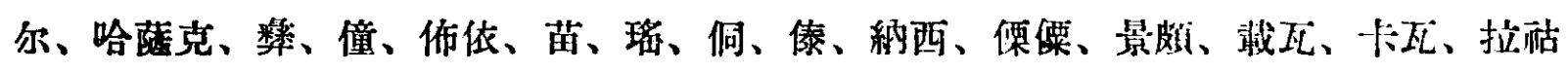
等 17 种語言的班次。为了配合創立偖族和苗族交字的工作，又开設了事修科，招收僮族 和苗族学生, 培养为語文研究和推行文字的幹部。为了淮一步培养少数民族語棓研究的 專門人材, 又开設了研究班, 研究生中有漢族也有少数民族。浯文系本科学生都必須到 民族地区实習一年, 先后派到度酒、貴州、四川、云南、新疆、湖南和西藏等处的实睗 組已达 32 个。培养幹部的工作都是和調查研究的工作相䊅合的, 中央民族学院語文系 8 个研組对少数民族語言也進行了調查研究。在各地民族学院和一些高等学校中，也有 开設一些少数民族語文課程, 並進行了研究工作的。語言研究所各工作榢都是一方面進 行調查研究，一方面進行培养幹部的工作，而且特別重視了培齐本上族語文幹部的工作。

上面那說各方面的調查研究工作，中央民族学院和其他学珫培养翰部的工作以及語 言研究所各工作榢在当地培养翰部的工作, 都給帮助少数民族發展語言文导的工作刢造 了必要的有利的条件。

\section{三 工作中的問题和对这些問题的看法}

根据过去的一些工作体会和苏联的先淮䊓驗, 我們提出有关帮助少数民族發展語言 女字方面的一些問題和我們对这些問題的初步看法:

\section{1. 关於調查研究民族語畐的方法問題}

㓣立、改進和改革文字的工作，都需要首先对同一語言的方言士語淮行調香研究， 文字方案的質量主要决定於调查研究工作的筫量; 即使在交字方案拟定以后, 也还需装 柪維做調查研究工作。因此，民族語文幹部应該十分重視調查研究的工作，並应随则改 進調查研究的方法, 以提高工作效率。我們認为在这一方面, 应該特別注意以下 4 个間 题: 
（甲）調查研究应該探取什么步驟?一一关於这个問題, 过去睹有兩种不同的看法: （1）先晋遍調查, 然后选定一种可以做标准語基礎方言的方言進行深入研究。(2)先任 选一个地区的方言深入研究, 然后淮行晋遍調查。这雨种办法我們过去都試用过, 实踐 告訴我們，这兩种办法都有缺点。用前一种办法就不可能在普遍調查以前对这种語言的

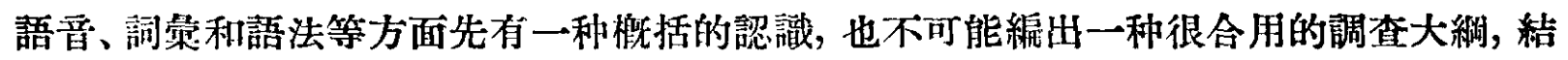
果会遗漏了一些語言特点, 在这一地区發现的問題在另一地区不一定有材料, 比較起來 很困难，也不容易得到正确的結論。用后一种办法, 只是孤立地了解了一个方言或士語, 对於其他方言士語完全不知道, 也不能編出一种很合用的調查大網，也不容易事先了解 哪些是这个語言的一般特点, 哪些是各地区的特点。这样也就不能保証下一步普遍調查 的效果。正确的做法是使重点調查和普遍調查適当地結合起來。这就是先在这个民族的 聚居区选一个地点, 就語音、詞巢、語法各方面進行相当媣入的調查研究。如果这个比 族的分布很度，有几个大聚居区，也可同时進行几个点的重点調查。在决定选哪个地方 淮行重点調查的时候, 可以向本民族訪問一些語言分布的情况做参考。有了重点調查的 材料以后, 便可以編一种初步的調查大綱在中央和地方的民族学院、幹部学校或短期訓 練班來自各处的本民族学員中進行調查, 在这炏初步調查里会發現一些方言或土語的特 点, 用这些特点糄成較完整的調查大綱以后, 再用这种調查大綱淮行普遍調查。在編制 調查大絧的时候, 还应該参考已有研究結果的親屬关系很密切的其他語言。过去我倗对 於編制調查大綱的工作, 沟有給予足够的重視, 経驗証明: 編制較好的調查大絧是做好 晋遍調查工作的必要条件。这样晋遍調查以后, 便可以根据調查的結果, 划分方言和土 語的区域, 选定标准語的基礎方言和标准音, 对於这个基礎方言和标准音進行深入研究, 並和其他方言士語或有密切联系的語言進行深入的比較研究。在普遍調查的工作中, 对 於各个調查点亚不是同等看待的, 应該根据本族人口聚居散居和語言敒成的情况选擇重 点和副点, 分別訂出对重点副点不同的要求。对於各个重点材料, 都应該說明它們適脂 的范葍，以便总結各个方言士語普遍性的大小。由於各个民族語言的具体情况利原有研 究工作的基礎不同，当然不一定对任何語言都呆板地探用这个步驟，不过我們認为在一 般情况下，这是一个較好的办法。

（乙）怎样划分方言?一一我們从前划分方言，过分地依靠語音，对於詞葘和語法沒 有予以足够的重視。一种語言的各个方言的基本詞彙和語法構造虽然大体一致，但是也 常常各有一些特点; 这些特点就是我們划分方言的主要依据。对於一种語言要从它的各 方面進行研究。由於各种語言的具体情况不同，我們在划分方言的时候，主要依据哪些 方面的特点也往往不同。例如：僮語北部方言和南部方言的美別，主要表現在詞急和語 音方面, 語法的差別很少; 傣語傣仂方言和傣哪方言的美別, 却表現在詞集、語法和語 音三方面。在一般情况下，在不同的方言中間，詞桑和語法方面的差別是主要的，但是 也往往还有語音方面的美別。在同一个方言区內划分土語的时候, 語音的差別一定是主 要的, 有些土語在詞彙方面也会有些差別, 語法差別几乎是沒有或者是很小的。例如: 僮語北部方言分 5 个土語, 南部方言分 3 个土語, 这主要是根据語音的美別, 这些語音 美別也是在音位数目的多少和詞的發音方面, 音節結棈是落本一致的; 但是其中也有較 小的詞彙上的美别。 
方言土語都是歷史范暸, 在進行划分方言的工作的时候, 还应該联系民薙的歷史。 人交方面的情况和交通不大方便的民族地区的自然地理情况以及各地区居比的自称，也 会有参考的价值。

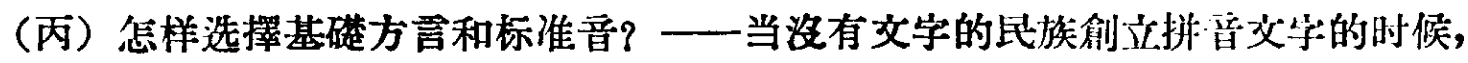
选擇基礎方言和标准音的工作是一件关鍵性的工作。在我們建設社会主义命会的國家 里, 当一种民族共同語的建立和發展时期, 凡是沒有明确的口語做基礎的拼音交字也必 須在現代口語中确定基礎方言和标准畐，使民族的北同語在活的口語基礎.上.發展起來。

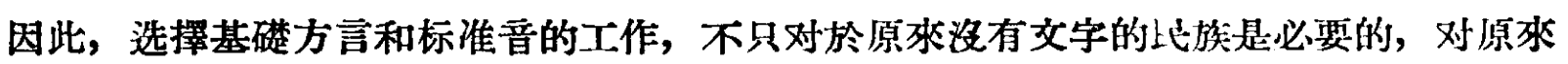
有交字而沟有建立口头的标准語的民族也是必要的。这一項工作包括以下的入容:

（1）搜集有关选擇基礎方言和标准音的材料：包括方言土語的分布、闹買和使用 的情况以及各地区在經济上、政治上和交化上發展的情况。

（2）在各种方言中选擇一种方言做基礎方言，再在基礎方言地区以內选定一个地 点的語音做标准音: 选擇基礎方言的标准主要有兩个: 一个是語言的普遍性, 也就是人 口的多少和地区的大小，一个是経济、政治和文化上的發展情况。这就是說，应当选擇 語言的普遍性較大的和經济、政治、文化上比較發达的地域方言做基脴方言。标准音应 該选擇緅济、政治集中和交化比較發达的地方的語音。如果一个地点的語音在人民䍿众 中已經建立了威信, 也应該做为一个主要营慮的条件。总起來説, 基礎方言和标准音不

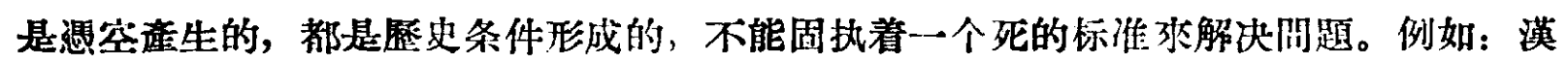

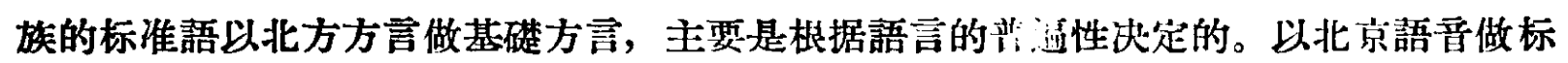

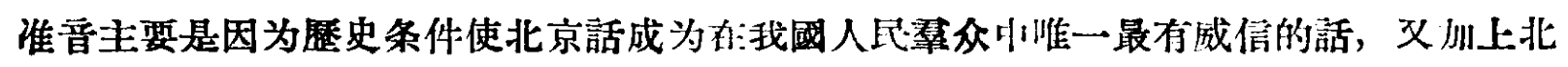
京是人民的首都，是我國政治、交化、經济生活的中心。僮族标准語选北部方言做基礎 方言, 也主要是根据語言的普遍性决定的。选武鳴語音做标准音, 主要是因为武嗎在誥 僮話的城市中是交化最發达的, 在地点上是僮族中心区, 靠近僮族的政治中心一一南寧, 在語言上也比較能照顧到南部方言。

基礎方言是一个專門術語。在一般情况下，做基礎方言的是一种方言。如果这个方 言內部包括一些音位系統不同的土語, 就要再选一个土語地点做标准音; 但是如果这个 方言区以內的音位系統是一致的，或一个民族的标准語是建立在一个土語的北礎上的， 基礎方言和标准音的范園就是相同的，也就用不着另选标准音。例如：我國景颇語有恩 昆、支丹、蒙支、嵪里 4 个土語，中間只有語音的差別，詞策除極个別的以外，完全一 致, 語法也完全一致。在这 4 个土語里, 恩昆的普遍性最大，我們可以选恩昆話做基碟 方言3 标准音也是恩昆語音, 自然就不能另外提出标准音的問題來了。在基碟方言和标 准音分开提出的情况下, 詞晕和語法要拿整个基礎方言做基礎（当然标准音地点的詞策 和語法也包括在內)，但是要依据标准音的音位系統。在不另外提出标准音的情况下, 那 就不只詞黨和語法，連語音也拿整个基礎方言做依据了。

（丁）怎样淮行下一步的研究工作? 一一选定了基礎方言和标准音, 就应該对於基 㯬方言和标准音的內部以及它們和主要方言的異同做深入研笲，然后拟訂交宇方案。文 字方案拟訂以后, 应該淮行以下的研究工作:

（1）㶌續研究正字法、正音法（包括借詞的正字法和正音法)，編寫正音詞典，使 
女字的形体和讙昔有一定的規范。

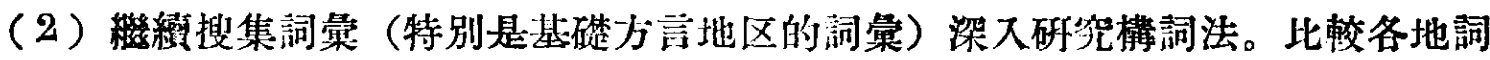

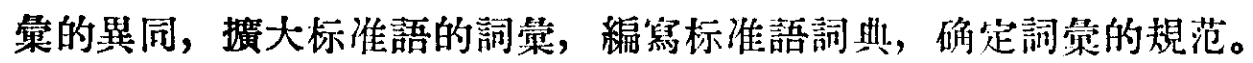

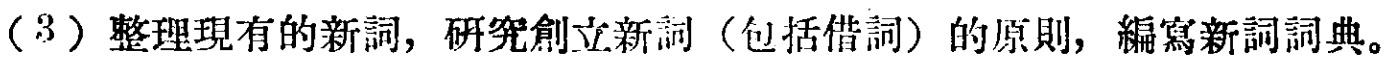

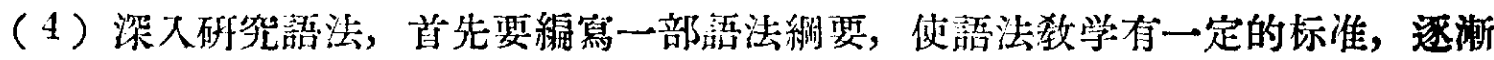
确定語法的規范。

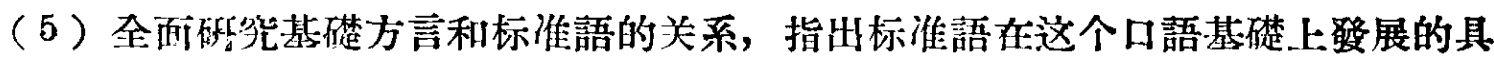
体道路。

（6）繼縜比較呼究各主要方言，編窵基礎方言以外的各主要方言区敉学标准語的 参考著。

（7）除了編寫民族語言教材以外，愔該研究践族語言和漢語的同巽，用比較的方

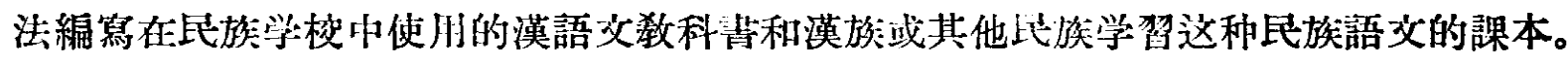

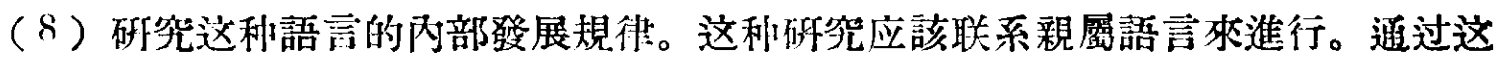
利砾究，找出正在生長着發展着的因素证促進它們的發展。这是一件長期的而且重要的 工作。为了做好这一件工作，应該組絨力县晋遍調查方言。这一次調查和为选擇基喽方 言進行調查的目的不问。这种調查越詳細越好, 不只要注意聚居地区也要注意散居地区, 不只要淤意城沁，也要注意绾村。

此外，应該及时检查並研究各方面实踐中所發現的闒題。对於用民族語交睪腺的政 策文作、文擎作品、报紙期刊以及敉学、啮播、戲剧、电影中所用的語言，都应該加以 研究，随时解决有关語言規范化的一切問題。这样才能促使書而的和口头的标准語迅速 而正确地發展。

\section{2. 关於拟訂文字方案的問題}

关於文字方案方面, 我們应該明确以下 4 个開題:

（甲）是不是一定走拼音交字的道路? —毛主席在 1940 年指出：“交字必須在一 定条作:下加以改草，言語必須接近堡众”，在 1951 年㕛指出: “交字必須改革，要走世 界交学基同的排音方淌”。当时毛主席是指漢字說的。漢字的歷史最久，交献最多，还要 走这个排音方们，其他比族文字当然也要走这个方向。拼音文字在所有交字結棈中是最 淮步的, 它能运朋几十个字母正确地全面地代表語言，对敉学、書宾、印刷、打字、打 电报也非常方便。不只新創古的交字必須是排音交字，原有交字不是拼音文宇的，在本 四族自願的原則下，也应該創造条件，逐汧地过渡到拼音文字。我國現在使用非拼音文

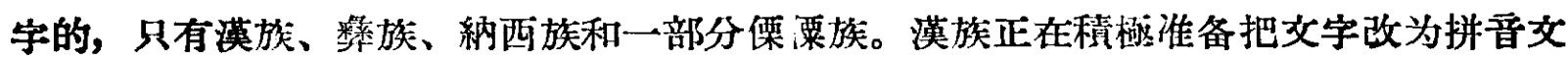
宇，䇣族也創立了一种排音文字，傈溧族也要統用一种拼畐文字，納西族也已經有人提 出拼音交字的要求。一切交字都必然地走向排音的道路，在我們淤会主义建設滈潮的推 动下，也必然会縮短这一过程。

（乙）創立交字的字母形式是否应該適当地求得一致？一为了便於各纪族交化交 流, 便於互相学㹦, 在帮助少数民族㓣文女文字的时候, 宇船形式应該尽可能地避免不必 要的分跂。特別是語言親屬关系很密切的民族更应該使用相同的字母形式。拼寫規則也 应該在可能范圈內求得一致。我國現有的拌音交字有蒙、藏、朝鮮、萠、傣、阿拉伯、 
拉丁、大寫拉丁字母的傈傈女、柏格里苗女、注晋字母等 10 种宇母形式。同一种字母形 式的交字在字母体势上和字楼数目上又有一些盖別。有一个民族使用完全不同的宇妇形 式的，如傣族的 5 种交字中，有 4 种是民族形式的，一种是注音宇母形式的。在 4 种民 族形式的文字当中，不只字母的体势有差別，宇母的数目也有相差很远的。傣哪交和侇

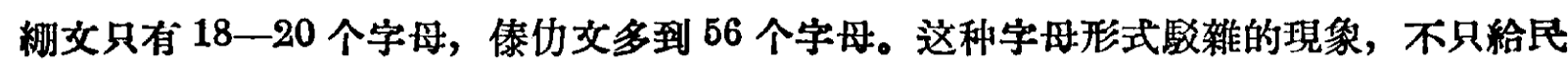
族語的發展和各民族互相学習带來了很大的困难，而且給國家統一計划出版、电报打字 机等項設备，增加了很重的負担，也妨碍了民族交化教育事業的展。今后在㓣安文字 的工作中，应該在統一的規划下处理宇母形式的問題。对於原有交守:的字母形式，应該 按照民族自己的需要和自願以及和別的民族的联系，考慮沿朋原來的字村:或改用別的字 母.

（丙）民族名称不同能否使用一种文学方䋈? 民族名称相同能否拟訂一种以上的文 宇方案一一文字是代表語言的，对於标准語的形成和發展也有很大的作㳉。民族名称不 同只要語言相同，使用一种文字没有多大困难的，最好拟訂一种交字方案，使用相同的 文字。这在政治、䉺济和文化建設事業的發展上，好处是很多的。比族名称相同而方言 差別很大, 在目前还不能使用一种文孕的, 也可拟訂一利以上的文字方案, 使州不同的 交字3 但要使字母形式和拼寫規則尽可能地一致, 以便於互相学習. 經过了一段几种女 字並用的时期以后, 再过渡到使用梳一文字的階段。例如：苏联的沃舍梯族过去創造了

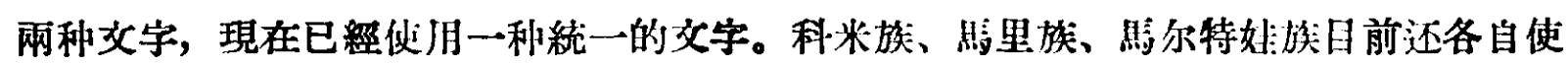

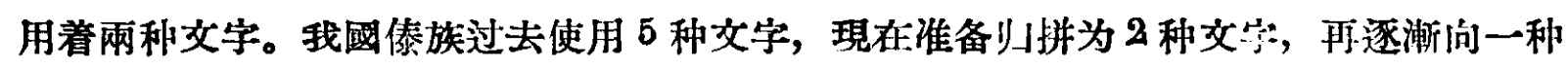
文字过渡。这样做对於普遍提高人民大众的文化水本是必要的。在们於会主义民族發展 的时期中，一个民族使用不同文字並不諮明它姴分裂成不同的民族。这些情况是摩史条 件造成的，如果人为地强調方言的差別或連方言情况也沒考慮，不必要地为一个民族刢 立不同的文字，那便是一种糪重的錯誤。例如：四川南部、貴州西北部和云南东北部的 苗語屬於同一个方言，帝國主义傳敉士却㓣造了兩种文字。景頗族內部證景頗話的利訜 戴瓦話的人是需要兩种文学的，可是帝國主义傳教士却在給筧景頗話的拟制了一种拉丁 字母形式的交字以外，父完全沒有必要地給說载瓦話的人拟制了字母形式不同的必利文 宇, 一种是拉丁字母形式, 一种是大察拉丁字母的变体形式, 而且分別印行了基督敉經

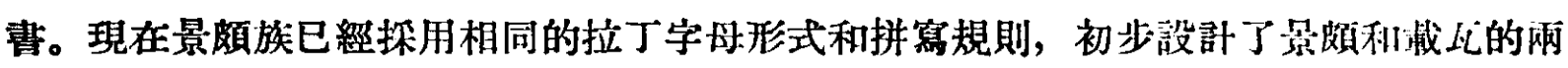
利交字改進方案, 准备取消一利載灭文, 我們認为这样做是完全证确的。

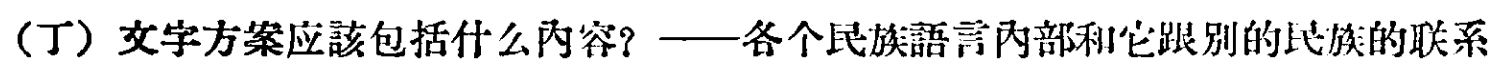
情况都有一些特点, 当然不一定各种文字方案都用一利第法; 但是一般地話, 制言丁一个 創立拦音文字的方案, 最好能包括以下的內容:

（1）民族的人口分布和語言使用的情况，

(2) 方言和土語的分布和差暴情况;

（3）基礎方言和标准音的选定;

(4) 标准音地点的音位系統; 应包括:

1. 音位的描窵和举例;

2. 音節結構的規則（漢藏語系的語言应該說明声、韵、調中間的关系，並附 


\section{一个声韵調配合的昔節全表);}

3. 标准音和主要方言、土語音位系統的比較;

（5）字母表（包括大小寫字母、正体、莫体）和字趾跟标准音地点音位系統的关 系（数碼最好探用國际通用的形式一阿拉伯数字，如果本民族原有晳用的数碼，願意 沿用的听其自願);

(6) 多音節詞的組成規律;

（7）拼窵規則 (移行的規則, 大䳆字母:使用規則和縮第規則也包括在內) 3

(8) 标点符号;

(9) 成箱交章举例。

如果是交字改淮方絮, 須在 (2) 項后加一項 “原有文宇的結構原則和使用情况”, （5）項改为 “原有交字的缺点和充实改進的方法”，在这一項里应提出新的字母表。原

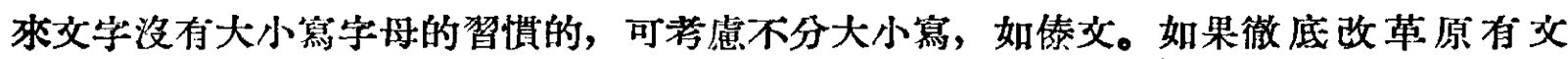
字，換一套新字舸，还应該境明改革的理由立提出旧文字过渡到新文字的办法。

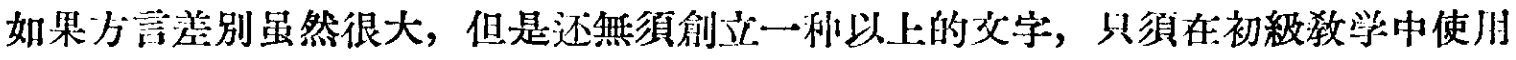
补充說明的办法解决学習的困难，也須說明使用这种补充办法的地区立提出具休的补允 办法。

\section{3. 漢語对於少数民族語兽的影响和少数民族、漢族互相学習語文的問題}

在多民族的國家內，一般都有一种各民族中間共同使用的交际語。汶种交际語往往

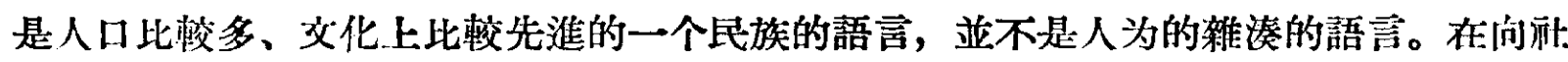
会主义、共產主义过渡的國家里，各民族团絬在一个統一的偉大的目标下共同地労动着， 一个全國性的各民族共同的交际語是必然嫳形成的。在苏联俄罗斯語言已經成为获联各 瓦族共闹的交际語，我國各此族也需要一种共同的交际語。从各方面的条件看，月月漢語 來做这利交际語是比較適当的。現在政府决定大力推廣以北方話为基礎方言以北京語音 为标准音的晋通話, 这对於各地漢族人民和各少数民族人民学㕷、掌握漢語, 将要起很 大的推动作用，各民族学習这种漢語普通話的姴求也必然日湓迫切，漢語对少数民族語 言的影响也必然日湓加多。闹时，在少数民族地区工作的漢族幹部和部榢学㕷当地比族 語言的泟求，也非常迫切。我們需要明确下面兩个問題:

（甲）在少数民族語言發展过程中应該怎样对待漢語的影响? 一一中華人民共和國 成立以桀，各民族語言中間呈現出互相丰富的現像，其中漢語对少数民族語言所起的良 好影响是比较大的。这种影响特別表現在詞鲳方面。不管是直接借用漢語或根据漢語的 詞义翻譯，都是丰富少数民族語言的一种重要手段。像“共迹党”、“解放軍”已經成为各 少数民族語言里步有的詞。这一类詞数的增長, 也就是祖國大家庭各民族語言的共同成 分的塯長，这对於各起族交化的溝通、政治上的团結和互相学拍語交，都起着巨大的作 用。应該指出，在目前漢語和少数民族語言的一部分翻譯工作中，还存在着兩种偏们： 一种是認为吸收漢語的詞就是沒做好翻譯的工作，即使在人民翠众中已經通用了的漢語， 借詞，也往往拒絕不用而另行創制一个对人民萦众陌生的詞 3 一种是不考慮本族語言里 是不是有適合的詞，也不考慮語言發展的內部規律，一味借用漢語的詞。这都是不正确 的。我們的意見是: 只要本族語言沒有合適的詞表达的, 应該考慮吸收別的語言特別是 
漢語的詞。人民娈众已經正确地吸收了的詞，尤其不能在翻譯工作中随意拒綛使用。这 些漢語的詞一緅吸收到自己的語言里就变成了自己的, 也䛮丰富了自己的語言。本族語 言里有合適的詞表达的，应該考慮用本族語言，但对於政治上有嚴畫意义的詞，应該惨 重考慮使不致引起誤会。例如：过去有把“斗孚”譯成“打架”的，把“帝國主义”譯成“洋 人主意”的; 如果在本族語言里找不到合適的詞, 就不如借用漢涪或其他語言了。漢語 对我國少数民族語言的影响也正如俄罗斯語对於苏联各少数民族語言的影响一样重要, 民族語文研究工作者和翻譯出版工作者对於怎样正确地墢揮漢語（我國北部鄰近苏联的 民族还有俄棓）对少数民族語言的影响这个問題，应該注意研究，梳重处理。这个間題 和少数民族文字的一部分正宇法也有密切的关系。

（乙）怎样把少数民族㓣立、改淮和改革交字的工作和民族語交的互相学㕷結合起 來? ——在我們学㕷另外一种語言的时候, 自然地会拿自己的語言和这种語言做一些对 比。可是没有代表自己語言的文学的人們，除非是專門研究过自己語言的，对自己的言棓

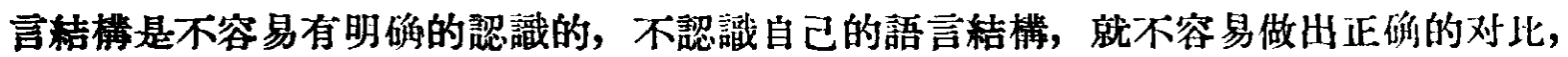
因而学㕷另外一种語言的效率就比較低。在有了代表自己語言的交字以后, 可以緗鼠大 家通用的本族語言和漢語对照的詞典, 用本族蔀言和漢語比较的方法編第語音課本和語 法網要，这样就一定能給少数民族中的漢語文敉学和漢族川的少数把族語交敉学，都提 供很有利的条件。可見, 少数民族有了交字以后, 更容易学劦漢語, 漢族也容易学䔠少 数民族語言 3 少数民族語言和嫨語也就更容易互相吸收自己語言中缺少的东酒, 这对於 少数民族語言和漢語的發展都是有利的。苏联各少数均族在創立發成了交字以后，不只 民族語言在迅速地丰富和發展，俄罗斯語在有民族交字的地区敉学效來地大大地提畣; 少数民族学校的俄罗斯族敉师，也很快地掌握了当地的上㵀語交。这充分說明了少数民一 族創立、改進或改革自己的交字是和他們学習漢語交以及漢族学晶少数上止族語文相絬合 的。政府早已从各方面鼓励少数民族地区的漢族幹部和部榢学㚙当地的比㵀語文。少数

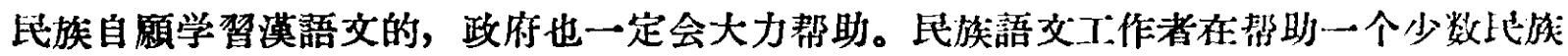
創立、改進或改革交字的时期，不能只編察民族語交的課本，还得运朋雨种語言比較的 方法編寫適合这个民族使用的漢語交課本和漢族学㚙这种民族語交的淉本，以便提鸩漢 語交在少数民族学校中的教学效率並給漢族学㚙当地民族語交創造更有利的条件。

\section{鼓铻}

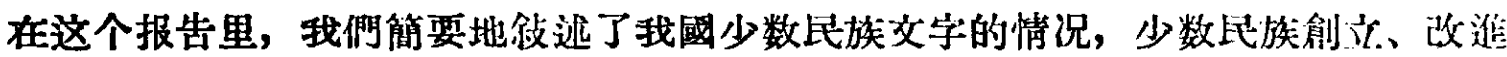

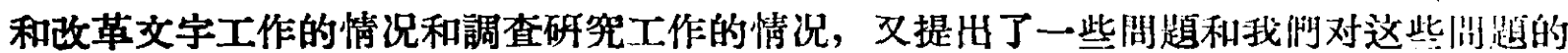
看法。希望同志們加以討論並批評指正。語言研究所在过去 5 年中，在帮助少数比放發 展語言交字方面做了一些工作，这些工作都是和有炎机構及本民族的幹部其晸進行的。 但是在工作中还存在着以下 3 个主要缺点:

1. 缺少全面的規划—1954年初，我們會䌈做过一个帮助少数长数發展語言文字的 八年計划, 但是这个計划对於工作方式和步㵵没有精密的規划，对於企四范湖內川以組

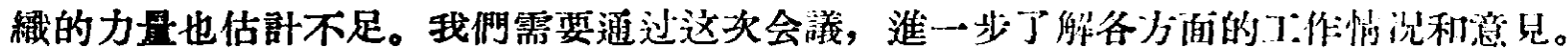
在会議以后，同有关方面詳細研究，在充分地估計全國現有的力量和新生力量的基礁 
上，拟定一个切实可行的長远的全面的計划。在这个計划中，对調查研究語言、拟訂文

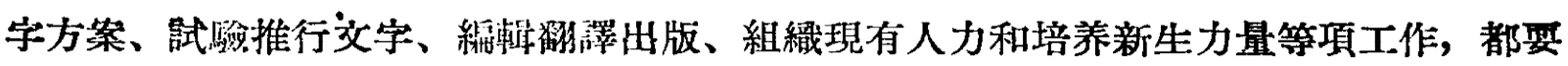
考慮效率最的的办法並規定开始和完成的期限。

2. 和有关机構的联系合作还做得不够一一过去虽然在許多調查研究工作中，和中央 民族学院、其他有关机構及本民族的幹部合作，立协助中央民族学院和地方淮行培养語 交幹部的工作。但是, 做得还很不够。例如：对中央民族学院的敉学工作协助得就不够， 在这次会議以前一直沒和柯孜勒苏柯尔克孜族自治州柯族文宇研究委員会联系过。今后 我們一定尽力組峨全國各方面民族語文工作的力量, 促使並加强各有关机粗的合作与联 系。希望有关机構也主动地随时和我們联系並督促我們的工作，特別希望本民族多有一 些同志参加昆族語交工作。

3. 没能乐时总結經驗, 提高理論水本一 5 年來, 在各方面取得了一些經驗, 但是 没能及时地邀請有关机構代表和專家進行比較全面的总結。也还沒能及时提出民族語言

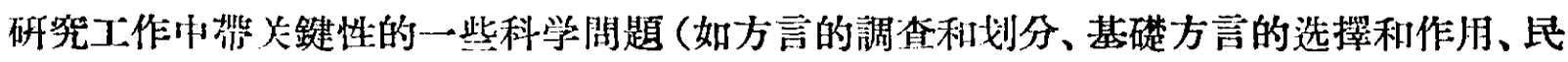
族語言的形成和發展等), 組緁力量進行研究。对於苏联的先淮經驗利語言科学理論学習 得也很不偧。例如：在僮語方言的划分上最初分北部和南部州个方言是正确的，但是却 錯誤地义在北部和南部各分出儿个方言, 直到苏联顧問謝尔久琴柯郄授指出以后, 才改 正过來。今后我們除了石开像今天这样包括行民族語言研究上一般問題的科学討論会以 外, 还要有訪划地召开一些各民族語言科学研究的尃阴会議, 以便澡入地討論各民族語

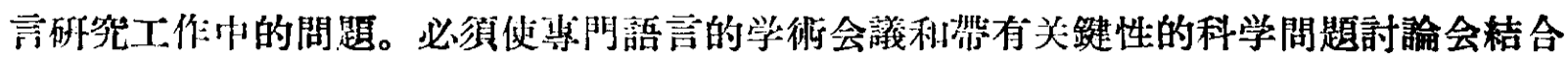

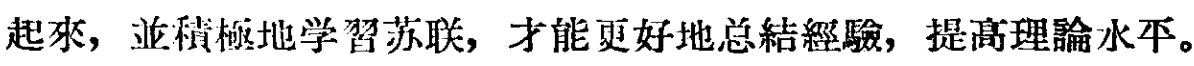

我俳的缺点当然还很多, 希望在这次会議中和会議后多多地随时地得到同志們的批 評。

同志們，再經过一段时間，我國就進入䒰会主义社会了。任何一个民族是不能帶着

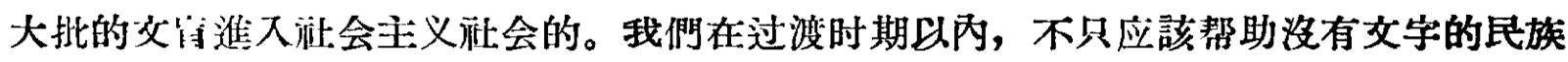
創汒文字, 帮助交字不完备的民族充实改進交字, 帮助需要改革文字的民族改革文字,

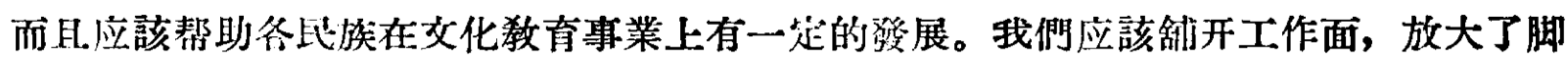
步, 放敢前進。我們有偉大的中國共產党和毛主席的領導, 我們有苏联的先淮經驗和顧

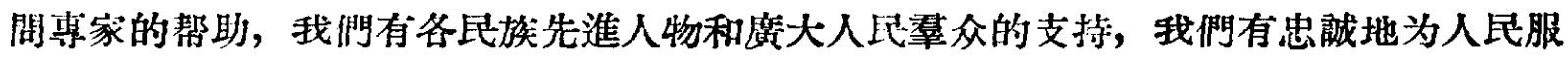
务的决心; 我荫光分相信, 全國民族語文工作少一定能更緊密地团結在一起, 勝利地完 成这个烺夏的、繁重的、光荣的任务! 